\title{
Reduction in deep sternal wound infection with use of a peristernal cable-tie closure system
}

\author{
Meghan M Stelly ${ }^{1 *}$, Charles B Rodning ${ }^{2}$, Terry C Stelly ${ }^{1,2}$ \\ From World Society of Cardiothoracic Surgeons 25th Anniversary Congress, Edinburgh \\ Edinburgh, UK. 19-22 September 2015
}

\section{Background/Introduction}

Deep sternal wound infections (DSWI) are a rare but serious complication after median sternotomy.

\section{Aims/Objectives}

We evaluated postoperative outcomes associated with two sternal-closure techniques.

\section{Method}

Methods and outcomes of sternal closure were reviewed in consecutive patients undergoing a variety of cardiothoracic surgical procedures. Sternal closure in the historical control group was performed using trans-sternal, stainlesssteel wire sutures; subsequent patients were closed using wire sutures together with a novel, peristernal cable-tie closure system to reinforce the corpus sterni. Perioperative care was standardized between groups.

\section{Results}

Between July 2010 and July 2014, 609 consecutive adult patients underwent sternal closure following open median sternotomy at a single hospital in Mobile, Alabama. Sternal closure was accomplished with wire sutures in the first 309 patients and with cable-tie reinforcement in the subsequent 300 patients. One author performed $71.8 \%(222 / 309)$ of the wire suture procedures and $92.7 \%(278 / 300)$ of the cable-tie procedures; the others were performed by a single other partner in his practice. Baseline characteristics were comparable between groups, except that the cable-tie group exhibited greater preoperative comorbidity. Mean body mass index was comparable between groups $(30.2 \pm 6.6 \mathrm{~kg} / \mathrm{m} 2$ wire suture versus $30.5 \pm 7.7$ cable-tie, $\mathrm{p}=0.568)$. DSWI occurred in $2.6 \%(8 / 309)$ patients in the wire-suture group, whereas no DSWI were observed in the cable tie

${ }^{1}$ Cardiothoracic and Vascular Surgical Associates, Mobile, AL, USA

Full list of author information is available at the end of the article group ( $\mathrm{p}=0.008)$. Analysis of STS data shows the authors' rate of DSWI to be $0.0 \%$ in each of the years from 2012 - 2014 (corresponding with adoption of the cable-tie system), compared to an overall institutional rate of $0.2 \%$ and an overall STS database rate of $0.3 \%$ for 2014.

\section{Discussion/Conclusion}

The peristernal cable-tie system was a simple and reliable method for sternal closure after open median sternotomy, and was associated with a reduced risk of deep sternal wound infection, even in an obese and comorbid population.

\section{Authors' details}

${ }^{1}$ Cardiothoracic and Vascular Surgical Associates, Mobile, AL, USA. ${ }^{2}$ Department of Surgery, College of Medicine, Medical Center, University of South Alabama, Mobile, AL, USA.

Published: 16 December 2015

doi:10.1186/1749-8090-10-S1-A213

Cite this article as: Stelly et al:: Reduction in deep sternal wound infection with use of a peristernal cable-tie closure system. Journal of Cardiothoracic Surgery 2015 10(Suppl 1):A213.

Submit your next manuscript to BioMed Central and take full advantage of:

- Convenient online submission

- Thorough peer review

- No space constraints or color figure charges

- Immediate publication on acceptance

- Inclusion in PubMed, CAS, Scopus and Google Scholar

- Research which is freely available for redistribution 